\title{
Radicalised Transformation, the Institutional Tensions and Modernisation Challenges
}

\author{
MILOŠ HAVELKA* \\ Institute of Sociology, Academy of Sciences of the Czech Republic, Prague \\ KAREL MÜLLER ${ }^{*}$ \\ Institute of Learning Foundations, Charles University, Prague
}

\begin{abstract}
The article attempts to theorise about the social changes mobilised by the transformation strategies in the countries of Central and Eastern Europe. It looks at what resources and actors have been mobilised, how they can be related to the institutional changes underway, and whether the emerging institutional changes towards competitive economic and political systems can be supported by efficient resource allocation and socio-cultural adaptations. In order to do this it is useful to refer to the current debate on modernity/post-modernity and its efforts to identify common practices or institutional forms coming out of the various developments in the advanced countries. The most appropriate patterns are discussed and applied as a framework for the assessment of the intended and unintended social implications of the economic transformation in the Czech Republic.
\end{abstract}

Czech Sociological Review, 1997, Vol. 5 (No. 2: 179-195)

\section{Introduction}

Observations of the ongoing changes in the countries of Central and Eastern Europe (CEE) are now indicating that the available political resources mobilised to serve the democratisation of the political systems of these countries have been exhausted, and that the transformation is challenged by more complex issues bound to economic, social and cultural interactions and more subtle ways of mobilisation. However, such practical efforts are associated with a lack of cognitive and regulatory capacities. As early as the beginning of 1990, J. Habermas correctly remarked that the transformation of the postcommunist countries was marked by the absence of any preliminary theoretical concepts or normative projects. Instead of classical revolutionary "innovative and future oriented ideas", more pragmatic models and sober efforts to "come back to democratic legal statehood" and to switch "orientation to the capitalist advanced West" have prevailed [Habermas 1990: 181].

Such pragmatic orientation has produced a specific reflexive framework which has accompanied the advancing changes. On one hand, it has been able to respond to the identifiable and changing public attitudes, on the other it has become difficult to assess (with distance and critically) the emerging implications of the undertaken steps. The prevailing orientation of transformation strategy towards issues of economic reform is an example of such a pragmatic approach. The technological and industrial gaps in relation

*) Direct of all correspondence to Doc. PhDr. Miloš Havelka, CSc., Institute of Sociology, Academy of Sciences of the Czech Republic, Jilská 1, 11000 Praha 1, phone + 4202242208 42, fax + 4202242202 78, e-mail havelka@soc.cas.cz or Doc. ing. Karel Müller, CSc., Institute of Learning Foundations, Charles University, Legerova 63, 12000 Praha 2, phone/fax + 42026434 725, e-mail muellerk@sun.izv.cuni.cz 
to the advanced countries and their implications for levels of consumption and welfare have been most apparent, and public opinion has understandably accepted the suggested path following the examples of the advanced countries. Consequently, economic competence has been accepted as the legitimate regulatory capacity able to exploit the available formal and informal capitals, i.e., the true guide of action. Such a positive coupling between the general endeavour of enterprise and the orientation of the transformation strategy towards economic issues can be well observed in the course of changes in the Czech Republic (CR), the experience of which will be at the forefront of the discussion on institutional issues. Moreover, the public debate on transformation has been reduced to issues of restructuring the economic system from etatistic regulatory patterns to competitive (open) forms. Within this perspective the essential question was formulated as follows: Should the state-owned enterprises be restructured in the course of their de-etatisation, i.e. by the the state in its fiscal and co-ordinative capacities, or should such restructuring be left to the privatised enterprises themselves? The latter perspective, which has prevailed in the public perception as well as in the predominant political view, does in fact suggest the implementation of economic reform in two steps - (i) privatisation and (ii) subsequent modernisation carried out by the privatised firms.

The economic reforms that have followed the democratisation process have produced quite strong effects of economic mobilisation regardless of the strategies (radical, evolutionary) which have been used by the respective countries. In most CEE countries, at least those which have had certain tradition and level of industrialisation, the period of recession has been comparatively short and economic growth has been good in terms of the macroeconomic figures. However, a closer look at the situation of the economic actors (firms) and the institutional framework of the emerging business enterprise sector (BES) indicates that the mobilisation effects produced by the economic reform are driven by various sorts of structural dependencies rather than promoting a sort of disembedding from the previous regulatory and self-regulatory patterns, promoting niches of innovative action (both in technology and regulatory forms), and shaping an institutional framework for a fair competitive environment. The radical course of the economic reform in the CR has produced such effects in quite an explicit form, as shall be discussed later.

It is suggested here that the implications of two radical reformative steps - the democratisation of the political system and the economic reform - are shaping the ground for a more extended and interactive reflexive framework of transformations. In the first period of transformations the more ideological and pragmatic approaches could prevail due to the weakness of systematic (expert) social knowledge and the rather utopian character of public opinion. Several essential issues are emerging which are already transcending the present political and ideological platforms. Firstly, the parallel and rapid transformations of the political and economic systems have not been able to dismantle the etatistic linkages and paternalistic (anti-meritocratic) inclinations which would encourage the functional disjunction of both systems and the promotion of their open and competitive forces. On the contrary, corporate patterns are re-emerging, undermining the effects of the liberalisation in small and medium-sized businesses, the service sector, regional initiatives and the role of professionals - and thus hindering the formation of the middle social strata in general. Such exclusions will not only undermine the needed shifts in social structures and value patterns, but narrow the base of legitimation and the capacities of the transformation efforts. Secondly, the rapid economic liberalisation and a weakened political culture and authority will sharpen the tensions between local, national and tradi- 
tional resources on the one hand and international and globalising pressures on the other. This may engender certain unpredictable impacts - either strengthen the position of regions and their globally active actors in relation to the authorities of the national state and produce the tensions in the national legal and political system, or limit the globalisation impacts while promoting an anti-foreign climate and excessive nationalistic feelings. Again, the control of these tensions will depend much on the capacities of socio-cultural mobilisation. In the economic system itself, the rapid and formal transformation (by coupon privatisation) was not able to produce effective change in the governance structure, nor stimulate the modernisation of the technological capacities and rationalise the firms' productive factors. It has been, in fact, a sort of 'zero-sum-game' redistributing the available resources to those with cultural capital (in Bourdieu's sense) potential. The impact of such social action and networking has followed to a great extent the most established techno-economic structures - manufacturing branches with unfavourable industrial capacities and social networks (such as production with high energy consumption, negative environmental impact and low technological demands and few innovation challenges). These branches have also been able to survive best the subsequent pressures of economic recession. Finally, the issues of violence, and control of the means of violence are of importance. The shifts from etatistic regulatory forms to effective self-regulatory action and initiative are much dependent on this issue since the uncontrolled diffusion of the means of violence, both in direct and formal state control and indirect and informal misuse of lack of rules and authorities, are in fact undermining the maintenance of the borderline between the legal and illegal arenas and actions and hence the legitimation of successful economic actions (and actors) and the motivation to legal action. It is suggested that the theories of modernity/modernisation and the debate focused on the understanding of the institutional framework of modern societies can form a fruitful cognitive framework to reflect critically the newly emerging consequences of the radicalised economic change and suggest an adequate concept for their understanding and control.

The debate on modernity/post-modernity issues offers a wide range of approaches reflecting the historical and formative bindings of the modernisation processes and their specific and diversified "processes, factors and causal patterns" [Hall, Gieben 1992: 1], the experiences of different regions and of civilisation spheres [e.g. Grasnow 1995], the growth and strategy options in the different levels of development [Wallerstein 1991], not to mention the classical works on this issue. The situation of the CEE countries is, however, marked by specific features which do not easily fit the assumptions made by these concepts. These features have been conditioned by the adaptive developments in the environment of etatistic (socialist) regulatory regimes. They can be seen in a specific coupling of radical industrialisation with an etatistic regulatory pattern which has been embedded in the specific economic (public ownership) and social (homogenised) structure, and has shaped specific socio-cultural adaptive patterns and tensions. They can be described as the embedded relationship between egalitarian tendencies and redistributive regulatory patterns with least motivation potential to individual action due to the prevailing antimeritocratic attitudes [Machonin, Tuèek 1994]. In institutional terms they were marked by the deconstruction of the borderlines between the economic and political system and between state and self-organised capacities of economic and political sectors.

Of course, such a situation has produced crucial tensions between the economic and social structure - advances of industrialism (and its shifts to more advanced technologies) and missing evaluative patterns for the efforts of the industrial actors and edu- 
cational, professional and innovative action in general. The real shape of these sociocultural patterns has become to some extent evident in the course of radicalised liberalisation. Whether, and how effectively they are mobilised in favour of and in response to new industrial and institutional options seems to be the crucial question of the social transformations which are addressed in this paper. The issue will be examined as follows: Firstly, the modernity/post-modernity debate will be outlined from the point of view of (i) common features of the modernisation process which might form a reliable guide for the assessment of (the direction of) transformations in the CEE countries, and (ii) the most appropriate concepts for the assessment of the crucial structural shifts in terms of resources and institutional patterns. In the concluding sections these shifts will be analysed and discussed with respect to the ongoing changes in the CEE countries and in the view of the chosen modernisation conceptual framework.

\section{Outline of the Suggested Concept of Modernisation Process}

As mentioned above this part is guided by the aim to assess both the common features (and problems) of the modernisation process as such and the specific adaptive patterns of the CEE countries which are usually described by the term transition or transformation. As stated earlier some modernity concepts stress and suggest the structural features of modernisation, and a certain convergence of the process. Others are more open and consider the direction of the changes to be the only meaningful feature of the concept. Moreover, the distinction between modernisation and transformation should be identified, in order to be able to apply the modernity concept in the assessment of the transformation. The following discussion will select from the available concepts and their cognitive assumptions such theoretical elements, or group of elements, which might help in theorising about the transformation in the CEE countries from the perspective of modernisation.

Here modernisation is understood as the evolutionary process in the direction of modernity. It differs from the notion of modernism (which represents the epoch following the New Age), or post-modernism (suggesting the overcoming of modernity). The modern epoch is characterized by the functional differentiation of sub-systems of society, the notion of modernity is used to define particular features of the developments of society since the Enlightenment. The following list enumerates such features: alphabetisation, secularisation, specialisation, industrialisation, urbanisation, democratisation, massification, emancipation (of individuals, groups, nations, cultures, gender), centralisation, automatisation, bureaucratisation (as the growth of administrative competencies both in the economic and political sphere), informatisation (technical and social), rationalisation, the growth of political participation and education - in their latest developments, for example, ecologisation, and miniaturisation. Such a list of the features of modernisation presents a first approximate account: it is a long term, deeply rooted, slow, uneven process with different temporalities, outcomes and unintended consequences which, however, indicates a certain pattern and formative power [Hall, Gieben 1992].

Modernisation is understood as a wider concept reflecting those political, social, economic, cultural and particularly civilisatory processes, and contemporary changes, which can be associated in a historical and systemic way with the processes of the New Age, the Enlightenment, and in particular, with dynamic industrialisation and its implications. The understanding of historical and systemic (formative) features should be sensitive to both technological and cultural factors and aware of socio-technical closures and their civilisatory implications. By that we avoid understanding modernisation as the dif- 
fusion of technological innovation mediating the spread of socio-cultural patterns from the centre to the periphery, which is at the core of concepts of westernisation or dependency theories. At the same time we see the limits of the concepts in which modernisation is understood as a dependent cultural factor - a view which is well-rooted in the Middle European context (see critical reflections of this in [Loewenstein 1990]), also present in different approaches of modernism or post-modernism. The positive coupling of both industrial and socio-cultural aspects can be found in those evolutionary concepts which take into account the growth capacities of both poles. S. Eisenstadt in this perspective suggests: "modernisation does not only mean the evolution (... measured by) various indices of the social mobilisation and growing structural differentiation but also such an evolution of social, economic and political system which not only creates permanent change but also is in a position to manage it by the help of its own institutional dispositions" [Eisenstadt 1973]. A similar approach is suggested by Giddens and Beck and will be discussed later.

The formative features of modernity can be expressed in the functional perspective as well as in the perspective of its content.

1) From the functional point of view it represents the novelty of trends, orientations, patterns of behaviour; it means the permanent openness of the ongoing changes, as well as the rapidity of the stabilisation and renovation of social structures and institutions under the pressure of economic, political, cultural etc. 'innovations'; a state of novelty opposed to everything that is assessed as old, traditional, left behind or inherited, petrified and sedimented.

2) From the viewpoint of content, modernity is understood as the principal intention of human action, thinking and creation, which cannot be ultimatively fixed, and which has the nature of oriented permanency of change and necessary openness that is associated with a well-defined notion of progress (in non-theological and non-utopian terms). Instead of the progress of humanity or awareness of freedom, the progress of technologies, knowledge, innovations, structures or systems is used.

In the sphere of knowledge modernisation is oriented towards the strategy of 'trial and error', it promotes the process of falsification and has the nature of permanent fallibility; in the sphere of the arts it is carried out by the continual actualisation of the relationships among aesthetical functions, norms and values; in the sphere of technology it faces the perpetual pressure of innovations; in the sphere of law it is marked by the continuous resolution of the tensions between the legality and legitimity arising out of the economic, cultural and social pressures on the legal framework.

The essential features of modernisation (by function and content) have been described on an abstract (theoretical) level, although certain examples have been mentioned in order to demonstrate their relevance in the social processes. The question can now be posed concerning how such characteristics can be applied on the level of social action and its institutional framework; how such a perspective can be related to the capacities of the institutions to reflect upon the changing environment and to respond to it by institutional change. The starting point is to refer to various socio-historical trends (or assumed relationships): it seems as though the progressing individuation process, and its consequent implications for the growth of political, social and human rights cannot be, mastered without free consumption, power sharing and reflexive action. Thus welfare resources, participative democracy and reflexive policy are important factors of modernisation. 
In extending the socio-historical background of the common features of modernisation, four factors can be distinguished to identify a productive (sociological) bridge to the understanding of the institutional aspects of modernisation:

i) the mobilisation of subjective and objective spheres of social life and individuals resulting in the intensified mobility of goods (the extension and intensification of the economic sphere, the standardisation of production, the productivity of economic factors, the solution of environmental issues etc.), social mobility (the productivity of decentralised systems, tensions between the centre and periphery, among the various forms of growth and decline of social status, between privileged and underprivileged urban areas etc.), and cultural mobility (forms of presentation and communication of needs and interests, changes in expectation patterns, value orientations) - in particular information mobility (promoted by various forms of mass media and advancing computerisation);

ii) Differentiation and specialisation, which are related via modernisation to the division of labour. At the same time, the possibilities of the internal stabilisation of the systems facilitated by qualified (differentiated and specialised) decisions and performance are becoming more evident. It should be stressed that differentiation and specialisation are not only more frequent than in the pre-modern societies, but also their content and forms change (the formation of new professions, the secularisation of the professions, the restructuring of status and roles, the growth of participation etc).

iii) Changes of values towards more universal and functionally specified value patterns associated with secularisation, which not only means the decline of various 'beliefs' and 'prejudices', but also the institutional disjunction of beliefs (and ideologies of various forms) from education; formal education is expected to shape and guarantee new forms of competence.

iv) A particular (and not always accepted) factor of modernisation is the capacity to institutionalise conflict (e.g. by help of projection into organisation patterns, modes of problem identification and solution, modes of decision-making etc.); such an approach is responsive to the controversial nature of modern resources and orientations (to freedom, empathy and solidarity, sympathy), and to the unintended and destructive impacts in the political, social or economic spheres.

The above outlined approach to the institutional issues of modernisation should be more closely bound to a more open and dynamic understanding of the institutional framework which would cover both the processes of de-institutionalisation and reinstitutionalisation. The radically disappearing etatistic, planned, top-down and hierarchical regulatory framework in the CEE countries, and efforts to establish open and competitive markets and civic institutions are shaping favourable and much-needed ground for this line of debate.

\section{The Institutional Framework in a Period of Radicalised Modernity}

In the current debate the institutional issues are assessed in a controversial way. On the one hand is the Weberian concept of institutionalisation as steadily advancing rationalisation and bureaucratisation which can be counter-balanced only by the heroic intervention of charismatic personalities. Much empirical evidence can be found in favour of the prevalence of such 'top-down' mobilising pressure. The emancipatory outcome of this situation is sought in various forms of critical reflections on existing institutions. For example, the post-modern approach identifies the 'overcoming' of such (top-down) pres- 
sure by events outside the existing institutions - at the borders of their fractured functions and aims. Other approaches stress (within the received sociological tradition) the role of communities and small social units as opposed to the great scale of formal and abstract systems of action. There is also enough empirical evidence about the success of the diversified strategies of such local and bottom-up initiatives towards the existing regulatory and organisational forms [see e.g. Eder 1990, Sennett 1994].

Zapf and Dierkes correctly suggest that attempts to overcome such a dichotomy have until now failed, since the study of institutions follows "two mutually isolated methodological and theoretical accounts: firstly, the formation of the institutions is derived from the actions of people; secondly, their prior existence is a precondition for the action of people" [Zapf, Dierkes 1994: 10]. Such isolated approaches always result in one-sided outcomes. Either the subordination of individual action to the collective framework is followed, which limits the options for understanding the institutional change, or, conversely, the subordination of collectivities to the individual is assumed, which leads to the extensive formalisation of action and the organisation framework.

A sound basis for the inter-related assessment of both perspectives in the analysis of institutions is provided by the structure-agency sociological approaches. Their feasibility is, of course, not only the result of the methodological advance of the discipline. It is the result of both the counterfactual capacity of sociology and the changes in the institutionalized practices themselves, which since the 60 s have begun to transcend the received structure-functional views. D. Bell in his fresh concept of post-industrial perspective foresaw radical changes of social and political systems [Bell 1973], yet still within the stability (and functionality) of the modern institutional setting because of its embedding in the cultural framework, i.e. in the sense of the Parsonian "cultural value-scientific integrate" [Parsons 1949, 1960]. In the 70s and 80s, however, more essential changes in value patterns were identified, if not always in readily apparent forms [e.g Inglehart 1977, Yankelovich 1981]. More transparent and significant events have been documented indicating the emerging cultural turn - a transition from the convention based pattern of values to one based on the postconvention [Habermas 1990].

In the sense of the above-mentioned evolution of the concepts of institution, and its socio-cultural circumstances, the 'institutions' can no longer be understood as mere senseless sublimations of purposes, norms and action able to prevent or inhibit human action. We understand them rather as cultural products expressing knowable practices of human interaction, or directly in the Weberian sense as specific 'chances' of action [Weber 1922]. 'Knowability' - as opposed to 'reasonability' - is laden with reflexive capacities: "the permanent monitoring of social practices in the light of incoming information about these practices themselves" - capabilities and capacities which can be labelled as institutional reflexivity [Giddens 1990: 38]. The study of the tensions, conflicts, legitimisation controversies and mistrust which arise at the borderlines of the institutions, or their interfaces, helps identify the orientations of institutions and so the context and sources of their potential changes as well.

After examining the basic features of modernity and its consequences for the concept of the institution the question can be posed with regard to what conceptual pieces can be picked up and used for a better understanding of the ongoing deinstitutionalisation in the CEE countries. If we return to the discourse which formulated the factors (or sociological aspects) of modernisation it can be seen that the socialist eta- 
tistic regulatory regime did, indeed, fail to balance and co-ordinate all four factors of modernisation. While promoting the techno-economic growth it became subject to differentiation and specialisation. However, being short of open, pluralistic institutions it was limited in the mobilisation of the subjective and objective spheres of social life, in the public assessment of the differentiated social claims and practices. From this point of view it can be assumed that an extensive institutional gap has developed in the CEE countries in relation to the advanced, democratic countries.

The implications of the institutional gap can be followed in the course of the transformation process, in particular through the mobilisation effects and the attempts at their (institutional) consolidation. Since these implications are rooted in the socio-cultural pattern, their analysis can be approached from various perspectives, and is associated with known methodological difficulties. Here only an analysis of the general institutional framework is intended. In this view at least two challenges or missions should be kept in mind which seem to be important for the possible route of socio-cultural shifts: (i) the formation of the basic modern institutional framework, the foundations of which have been, in some socialist countries, de-constructed, or in others had no roots at all, (ii) the implementation of the political and regulatory practices which acknowledge the institutional gap, its socio-cultural background and possible routes and resources to overcome it. Here, it is necessary to mention the phenomenon suggested some time ago by Veblen as the advantage of the latecomers (or those lagging behind). Recently, its feasibility has been well-demonstrated by the developments in the East Asian countries. It is the aim of the above suggested missions to keep in mind such an option. The first approach, the formation of the basic institutions, stresses the functional aspects, the latter ask whether de-institutionalisation, and active experimenting in the search for standard modern institutions can be promoted by a more open kind of knowledge production, which is suggested by the concept of reflexive modernisation [Beck, Giddens, Lash 1994]. An outline of the main features of both suggested perspectives will be presented since it is in our view useful for the analysis of the institutional changes in the CEE countries.

A more evolutionary structural approach is suggested by W. Zapf and applied in the analysis of the transformation of the New Federal Countries [Zapf 1994]. He makes use of two essential ideas of Parsons which he finds appropriate for understanding modern societies, and in particular for the institutional capacity to change. First, the so-called "evolutionary universals of society" - social structure, cultural legitimation, rational legal system, administrative capacities, monetary market system and democratic associations, which he reformulates in a more direct way as the institutions of competitive democracy, market system, welfare society with mass consumption and welfare state. Secondly, development is understood as the combination of inclusion (of new groups into the basic institutions), value assessment to more general orientations (a high flexibility of the diversified cultural symbols within the basic values), differentiation (in the sense of institutional innovation) and status enhancement (as the growth of welfare and social competence for many citizens, and basic social and political rights).

The institutional aspects of the reflexive modernity concept are best outlined by the so-called institutional cluster of modernity suggested by Giddens [Giddens 1990]. It is worked out on the same (meso-) level as Zapf's model but in a more extensive and dynamic framework. In his model the driving forces of modernisation are seen in balancing the processes of fragmentation and displacement with the trends of globalisation and in- 
tegration on the one hand, and the balancing of the trends to violence and surveillance with the opportunities of freedom of speech, participation and dialogue on the other. The key institutional dimensions (organisational clusters) of modernity are connected with the capitalist system, and industrial system (as general efforts to form 'artificial nature', domesticated nature). The integrity of modern society is conditioned by the role of the (national) state in the surveillance of the relevant population and territory and control of the means of violence (their monopolisation and the consequent pacification of social relations). Institutional reflexivity is influenced by the many-sided interfaces and interactions among the mentioned institutional perspectives (e.g. the industrialisation of capitalism, the etatisation and industrialisation of war, etc.); the resources for such interfaces are related to the capacities to identify unintended implications (which in his view rest both in the design of modernity and the 'failure' of the human factor), the circularity (reflexivity) of knowledge systems, power differentials and shifts in valuation patterns. The countervailing (subjective) resources are specified in the reflexive politics and social movements since he is counting with the diarchic (controversial) nature of modernity.

The above-mentioned outline of the institutional cluster of modern societies stresses in particular those features which are basic and common in shaping modern institutional forms and environments, and which might be taken into consideration while analysing the situation of the institutional changes in CEE. However, it should be kept in mind that these concepts do not, of course, give a full and clear-cut picture of the issue. In particular, the concepts of reflexivity are still a subject open to debate. While there is consensus on the understanding of reflexivity as different from reflexion (science based discourse) there is no consensus on the nature of reflexivity. While Giddens assumes a well monitored and trust-based interaction of (abstract) expert system with symbolic tokens, Beck argues that non-knowledge and overwhelming risks are typical for the modern situation, and Lash finds that the concept of the institutional reflexivity is short of hermeneutic cultural resources [Beck, Giddens, Lash 1994]. These conceptual differences might all be accepted in the analysis of the situation of the CEE countries in the sense that they describe the interactions of the basic cultural sources of modern societies - science, arts and morals - and the re-foundation of this cultural framework is an important mission and pre-condition of the transformation process. The second inconsistency of the suggested approaches is related to the combination of different concepts of institution for the analysis of the present situation of the CEE countries. Indeed, Zapf's approach is based on the Parsonian functional and consensual approach while that of reflexive modernisation is based rather on the potential of differentiation, dissent and borderline approach. While the CEE countries are facing a sort of radicalised (double mission) modernisation - to refound basic modern institutions (in Zapf's approach) and at the same time to face postmodern challenges - both concepts are suggested to help selectively theorise about the possible course of re-institutionalisation in the radicalised developments in these countries.

\section{The Institutional Tensions of Transformation Processes in the CEE Countries (with par- ticular reference to the situation of the Czech Republic)}

In the preceding parts we have suggested that modernisation can be understood as the aim of the transformation, or as its energy, or as both. There is, however, an essential difference between the notions of modernisation and transformation. While the modernisation represents a certain orientation, intention or inclination, the transformation is character- 
ized by specific aims which can be followed by specific strategies, well-selected means or resources (like de-etatisation, privatisation etc.). However, as suggested above, modernisation concepts offer, with the exception of general functional and content-like characteristics, certain structural patterns indicating formative factors, resources and relationships which can be applied in the assessment of the transformation strategies and their implications. The general modernity characteristic (of evolutionary and innovative tendencies) has been re-formulated into a more instructive approach which understands the transformation as a confrontation of structural dependencies and mobilisation effects. ${ }^{1}$ Moreover, the resources of both sides are specified by their diachronic nature. While the basic institutional framework (in Zapf's interpretation) is marked by discontinuity (from an etatistic to a competitive pattern), the particular (local) resources have a continuous (or evolutionary changing) nature. In the first steps of the transformation process, which followed political aims, the discontinuities were in the forefront of public attention and were able to legitimise the economic reform and its political actors even though it combined rather utopian visions with pragmatic decision making. The advance of the economic reform, and the emerging socio-cultural tensions, are revealing more the continuities of local (or traditional) resources and the more complex nature of their change and consolidation. Here, we are facing more general questions which have been already hinted at in the introductory section: how far was socialism modern, has it formed some modern resources, that is to say what is the shape of the structural dependencies influencing the transformative efforts?

The question of the relationship between socialism and modernisation is not new but the rapid collapse of the former socialist bloc has led to its better specification. In the 60 s two contradictory solutions were suggested. Firstly, the neo-conservative concept of post-industrialism of $\mathrm{D}$. Bell which anticipated the convergence of capitalism and socialism on the basis of the social implications of industrial shifts [Bell 1973]. The convergence concept has also been assumed in most reformist socialist concepts. Secondly, the position of critical theory and its concept of 'late capitalism' [see Glatzer 1991], which has stressed the necessity of more substantial social and institutional changes transcending the prevailing forms of social (capitalist) order.

As indicated above the present concepts of modernity have departed from the polarity of such views but have not accepted one-sided liberal concepts of 'the end of history'. From such perspectives the socialist efforts can be understood as a specific modernisation step, and in two aspects: (a) in their ideal perspective, original intention and starting mobilisation effect, and perhaps reformative efforts (since the 60s) as well as (b) in their decline, which was actually brought about by global modernisation pressures which deconstructed and delegitimised regulatory patterns based on a one-party political system and a planned, command economy. Beck's specification of the modernisation process into two phases - simple and reflexive modernisation - seems best fitting to interpret this issue [Beck 1986]. The socialist modernisation efforts were developed within the framework of simple modernisation: their institutional context was based on the assumption that the growth of (expert) knowledge and technology is correlated with more reliable control of the natural and social environment. Such a perspective led to the growth of the techno-economic system (close interactions among the economic, industrial

1) In this concept we combine Stark's approach of path dependency with Eisenstadt's mobilisation concept. 
and political systems) and the suppression of the countervailing civic and emancipatory arenas and forms. This technocratic growth (of simple modernisation) was felt in the 50s and the $60 \mathrm{~s}$ in general. Yet, in the socialist bloc - due to the de-construction of the institutional universals (competitive market, pluralist political system and professional and civic autonomies) - the development followed a specific (even anti-modern) route.

The understanding of the above-mentioned point (b) - the adaptive steps of the socialist regimes and social environments to modernisation pressures (and the growing techno-economic gap with the advanced countries) - is of crucial significance for the comprehension of the means of the current transformation processes. Due to the decline in resources and institutional capacities, this period (of the 70s and 80s) can be labelled as a period of late socialism.

The socio-economic tensions and contradictions in the period of late socialism and the attempts to reconcile them, took on different forms in the individual CEE countries. These forms have already indicated different modernisation resources - some experimenting with the regulatory patterns and forms of social mobilisation (such as Poland or Hungary), others went on to mobilise their industrial resources with the expectation of closing the technological gap with the modern world. The Czech lands belonged to the latter group, and their modernisation resources, as well as their institutional implications, have been already anticipated in some earlier studies and described in follow-up research into the transformation process. For example, the techno-economic indicators of the various manufacturing industries have been monitored for two decades indicating a growing technological gap within the diversified pattern of industrial structure [Kolanda 1992] and the unreadiness of the industrial infrastructure for the 'implantation' of high-tech manufacturing; consequently, the traditional (medium and low-tech) industrial branches have absorbed most of the available resources mobilised by the economic reform. The adaptive behaviour of enterprises under such industrial constraints have been clearly identified by Mlèoch, which he calls non-parametric and lobbying behaviour [Mlèoch 1992] - corporate behaviour well fitting into the redistributive, egalitarian and anti-innovative nature of the socio-economic system. Socio-cultural implications have been identified which accompany the growth of anti-meritocratic and traditional orientations [Machonin, Tuèek 1994]. The industrial capacities (of science, technology, education, and services) have been expected to form the mobilising (continuous) resources of the transformation process. However, the radical change in their socio-economic environment not only revealed some localities capable of surviving but also extensive communicative and interactive deficits and a weak institutional background [Müller 1993].

All the above-mentioned studies of late socialism indicate that some important (adaptive) shifts in power distribution within the socialist institutional framework occurred. These were marked by the growth of the power of localities (complementary to the decline of centralistic power) and carried out predominantly by informal sources and networking. They shaped a sort of pseudo-market (black economy), self-organising activities ('second society') and a re-orientation to foreign patterns (with a loss of trust in domestic capacities). Within such a regulatory framework many local activities became differentiated and were able to stimulate functional growth but their status (and public assessment) was problematic, as the post-revolutionary events have indicated. Namely, due to the absence of public communication arenas such bottom-up actions and networking it was not possible to facilitate both public discussion and evaluation and the actor's 
self-actualisation and responsibilities based on public frameworks. This could not, of course, lead to 'visible' evaluation, and shifts in values, risk assessment, mobility shifts and the institutionalisation of conflicts. On the contrary, the tensions between the formal and informal evaluations accumulated within the existential knowledge of individuals and knowledgeable practices of institutions.

This analysis of the developments of late socialism, and their institutional implications, show the pattern of the institutional gap which has emerged in relation to the advanced industrial and democratic countries. Its features are even more evident if we look at the institutional framework from the perspective of reflexive modernisation. Even though late socialism development was characterized by the decline in the resources of the centralistic power, and the emergence of local, bottom-up niches of action, this did not constitute a bridge to the modern institutional pattern. The resources of the 'black economy' and 'second society' were shaped by a rejection of or confrontation with public aims. They cannot be considered as functioning as the resources of re-institutionalisation, either in the constructive or reflexive perspective. In this sense the institutional adaptations in the period of late socialism were diverging from the general modernisation route. The radicalised transformation steps have disclosed these divergences and the forthcoming transformation strategies will have to take into account their socio-cultural impacts. In this sense Machonin is correct in labelling late socialism as "a repeated dysfunctional extensive industrialisation" [Machonin 1996: 177]; it has created the limits to the postindustrial challenges [Bell 1973] rather than the resources for the radicalised modernisation as was expected by the aims of the strategy of the economic reform in CR. In order to study the institutional changes more closely it is necessary to abandon the general view of the situation of the CEE countries and focus on the situation in the Czech lands.

The impact of the structural dependencies on the interaction of the (top-down) regulatory steps with the mobilisation shifts seems to be the crucial framework for the institutional change. It can be observed in various areas and is reflected in critical studies. For example, a study of the post-privatisation economic situation (and the strategies of its actors) indicates that the differentiation into the standard management, employee (trade union), and public (state authority or consumer associations) sectors and actors is still led by structural paternalist dependencies rather than being mobilised by liberal patterns [Vláèil 1995]. Similar dependencies have been identified in welfare and social policy issues [Veèerník 1996], and in the emerging pluralistic political system by Novák; in his view the 'anti-system' parties - a phenomenon of the structural dependence in the political system - are undermining productive alternations of governments within the competitive political environment [Novák 1995].

In order to give a systematic picture of the above indicated institutional tensions the application of the notion of the institutional cluster of modernity is suggested. Since the institutional adaptation of the transformation process faces a double mission - to form a basic institutional pattern and to promote the reflexive capacities of the institutions - we suggest the application of two blocs of modernity concepts referring to this issue: Zapf's concept of institutional patterns of modernity, which offers an insight into the problems of the first mission, and the concept of Giddens which tackles the latter. Of course, both perspectives will produce contradictory pictures of the changes for conceptual as well as analytical considerations (indeed, the clash of the top-down regulatory steps and the responsive bottom-up actions is laden with extensive conflicts). For this reason it is best to 
follow the emergence of the institutional tensions at a meso-level - along the borderlines between the elements of the above mentioned institutional cluster of modernity.

In accordance with this approach the niches of institutional tensions can be specified in the following areas and forms:

i) In the sphere of economic system, and the situation after the radical (mass) privatisation, the basic line of tension (in relation to the basic institutional pattern) can be observed at the borderline with the political system (and state) on the one hand and the industrial system on the other. The formation of market institutions, and the insulation of their functional (parametric) aims from political and industrial aims, is adversely affected (corrupted) by the revival of corporate patterns backed by the informal interfaces to both the regulatory authorities and the dominant (extensive) industrial and financial actors. Instead of becoming public, open and interactive, the emerging market institutions are retaining features of sectoral, corporate and closed orientations and actions. On the other side, the mobilised innovative market actors and niches of enterprise are constrained by the limited capital resources, the insolvency of economic actors (limiting the scope of economic exchanges) and the fragility of contract relations.

These contradictory pressures can be, for instance, explicitly observed in the course of the formation of the banking sector, which is an important factor of accumulative economic capacities and in this sense also an intermediary actor between the political and industrial systems. Its involvement in the radical privatisation has extensively drained the available domestic capital resources by risky credits (amounting to more than one-third of total credits) and its actors formed networks with the large companies. Consequently, the available capital was mostly deployed in traditional industrial sectors. Their formative role and capacity in promoting the prospective areas of enterprise (e.g. the small and medium-sized business, or more advanced technologies) has been blocked by the lack of capital, expertise and foresight. Consequently, the de-etatisation of the banking sector has been halted, signalling not only a uncertain situation for the monetary control of the economic system but also the formation of the corporate linkages among the banks, executive and industrial sectors. Similar problems are emerging in the fiscal area and its mediating role to the public services and their institutions.

The continuing exclusion of the small and medium-sized businesses, technologybased manufacturing with a higher level of sophistication, and the lagging transformation of public services are depriving the liberal orientation of the economic reform of its social support and long-term competitive resources.

ii) In the sphere of the political system the main line of tension (excluding the abovementioned interfaces to the techno-economic structures) is shaped at the emerging borderline between the state, with its surveillance function, and bottom-up action and movements claiming local or regional political, social and human rights, and reestablishing their self-organising function. The manifestations of these tensions can be observed in various areas: the formation of a decentralised administrative system, regionally or ethnically-based public initiatives, professional associations and the strategies of public movements. The formation of this borderline is suffering from both the prevailing centralistic pressures, and missing evaluative responses to local action, and local action limited to narrow, short term orientations. The more general indication of these institutional tensions is signalled by the differentiation of the political sphere as well as the limited growth of its power-sharing capabilities. Such a situation is under- 
mining not only the productive alternations of governments, as mentioned above, but also the productive competition between political visions and the formation of their conceptual platforms.

iii) In the sphere of industrial system, and its restructuring into a post-industrial pattern, including the transformation of its crucial institutions (of science, technology, education and other public services), institutional tensions can be observed on two levels: in the course of the formation of the borderlines (1) between the system of expert knowledge (in academic institutions and professional communities) and professionals in the administration, business and other social institutions, and (2) between the sphere of expert knowledge actors and lay actors; even though the platforms of professional autonomy have been re-established, the weak communicative interfaces among the institutions persist and limit the process of public learning and action in the appropriation and control of modern industrial resources. For these reasons the formation of intermediate capacities (between academic and industrial science, between the scientific disciplines and educational subjects, and among the professional communities), which is the important factor of re-institutionalisation in this sphere, is weak and hence the restructuring of the institutions themselves is lagging behind. The communicative competence of the knowledge-producing institutions is of particular importance for the mobilisation of the socio-cultural patterns and the reflexive capacities of the political system and its actors. Both of the above-mentioned institutional tensions are limiting the mediating (comprehensive, counterfactual) role of expert knowledge institutions between routine social practices and political efforts to shape realistic future-oriented programmes. The growing public influence of local, partial, unjustified or utopian visions, and the general decline of public expectations, are the other side of the coin.

\section{Discussion}

The aim of this paper has been to suggest the appropriate modernisation framework, or at least assemble some pieces of received modernity concepts, in order to assess the political, economic and socio-cultural transformations in the CEE countries. Within this perspective more detailed attention has been paid to the problem of the institutional issues which have emerged out of the de-institutionalisation of the etatistic regulatory system. The analytical insight has been supported in particular by an outline of the institutional tensions resulting from the radicalised economic reform as pursued in the Czech lands.

With reference to the conceptual considerations, and the institutional issues identified, the current transformations in the CEE countries can be understood as a reaction to a robust modernisation pull. The pull effect has been shaped by the political will and the public desire to adopt and achieve the socio-economic framework of the advanced countries on the one hand, and the radicalised reformative strategies (liberalisation, privatisation), which have been thought to produce the adequate mobilisation effects, on the other. The robustness of the modernisation impact is seen in two aspects: (i) in the gaps concerning the (objective) economic and industrial resources, and (ii) in the institutional deficits which have arisen in the relation to the (unexpected) implications of the liberalised economic and political environments. These institutional challenges are not only associated with the radicalised transformations of the regulatory systems into liberal and competitive frameworks, but particularly with the simultaneous transformations of both the economic and the political systems, and the necessary maintenance of the administra- 
tive and welfare distributive functions of the state. In comparison with the other attempted routes of modernisation in recent times (East Asian, South American or Spanish) this is a historically unique situation which is producing extensive social tensions and costs that are bound up with the reformative efforts.

So far, the emerging problems have been identified in economic terms as the growing external and internal indebtedness of firms, the tight fiscal situation, monetary problems (devaluation or re-valuation of the exchange rate), high inflation, decapitalisation and so on. Indeed, restructuring the economic system into a standard competitive and efficient form is an independent and powerful factor of modernisation. It is an important resource in the control and the restructuring of the welfare roles of the state and in the recovery of the industrial system, which can feed back the resources of economic growth. However, the parallel transformation of the economic and political spheres does not allow for combining compensatory effects of advances and setbacks in both spheres, to establish a reliable path of growth. On the contrary, a mutual draining can be observed - both in terms of the monetary resources and authority. Consequently, the transformation of the public institutions is lagging behind and exerting massive pressure on the state budget. Indeed, since the instruments of public authority are very provisional, the issues of public institutions are reduced to the fiscal or financial aspects and thus facing insurmountable limits to their change. On the other hand the formation of the BES is suffering from a legitimation deficit. Thus, the main line of conflict is located between the emerging private sector, and its enterprising vigour, accumulative effects, including its professional, small business, middle class and liberal infrastructure on the one hand, and the public sector with its welfare, public services, public knowledge and political functions including its communicative cultural background on the other. Direct confrontations between both spheres of action (and the missing mediation between them) are strong enough to undermine the effects of economic mobilisation and release the impact of various elements of structural dependencies.

Within the followed modernity concept, and the focused attention on institutional aspects, it is suggested that the further advance of the transformation process is conditioned by the capabilities and capacities to specify and solve the emerging interinstitutional tensions and conflicts. These are usually resolved in a pragmatic way (on a case-by-case basis) instead of being institutionalised. The institutionalisation of conflict is, of course, conditioned by the capabilities to mobilise socio-cultural resources. It can follow either a very narrow (inflexible) or a wider and more flexible scope and route in processing the shifts in value orientations. At least two of the above-discussed aspects seem to be important for the productive or destructive outcomes of such shifts: (i) the promotion of the legitimation arena by the inclusion of emerging social claims and the formation of conceptual platforms which would extend the power of the evaluative processes, and subsequently the effectiveness of ongoing social differentiation and growth; the constrained course of such development is engendered by the absence of such concepts and platforms, their limited legitimation power and the consequent process of social exclusion, the ideologisation of public reasoning, and the tense social environment, and (ii) the formation of intermediary capacities and capabilities which would avoid the direct confrontation of institutions (and possible consequent deterioration of relations, or corruptive impacts), promote their internal transformation by the help of external sources and thus the formation of effective and interactive capacities of institutions. 
KAREL MÜLLER works in the field of social studies of science and technology. He graduated in economics and his post-doctoral study focused on the problems of R\&D economics. He later conducted research at the Academy of Sciences, having taken part in the interdisciplinary studies of the implications of S\&T. He focused on sociology, more specifically on the empirical study of research institutions in the social context and modernity concepts. At present he is teaching at Charles University, lecturing in the field of the sociology of knowledge, innovation and modernity. MILOŠ HAVELKA graduated from Masaryk University in Brno. Cultural editor of a Brno daily newspaper over the period 1968-1970, from 1970, he was researcher at various institutes of the Academy of Sciences in Brno and Prague. He specialised in the history of sociology and systematic problems of social philosophy. He recently edited and contributed to the publication, The Controversy about the Meaning of Czech History 1885-1938 (Prague, 1995). His book Max Weber. An Introduction to His Thought as an Introduction to Social Philosophy is forthcoming. Since 1994, he has been Editor-in-chief of the Sociologický èasopis and the Czech Sociological Review.

\section{References}

Beck, U. 1986. Risikogesellschaft. Auf dem Weg in eine andere Moderne. Frankfurt am M.: Edition Suhrkamp.

Beck, U., A. Giddens, S. Lash 1994. Reflexive Modernisation, Politics, Tradition and Aesthetics in the Modern Social Order. Cambridge (UK): Polity Press.

Bell, D. 1973. The Coming of Post-Industrial Society: A Venture in social forecasting. New York: Basic Books, Inc.

Eder, K. 1990. Kollektive Akteure zwischen Identitaetssuche und Mobilizierungsindustrie. Hamburg: Hamburger Institut für Sozialforschung.

Eisenstadt, S. 1973. Tradition, Change and Modernity. London, New York: John Wiley.

Giddens, A. 1990. The Consequences of Modernity. Cambridge: Polity Press in co-operation with Oxford: Blackwell Publishers.

Glatzer, W. (Hrsg.) 1991. Modernisierung moderner Gesellschaften. Frankfurt am M.: Westdeutscher Verlag.

Grasnow, B. 1995. “Chinesische Modernisierung und kultureler Eigensinn.” Zeitschrift für Soziologie 24: 183-195.

Habermas, J. 1990. Die nachholende Revolution. Frankfurt am M.: Suhrkamp.

Hall, S., B. Gieben (ed.) 1992. Formations of Modernity. Cambridge (UK): Polity Press with Open University.

Inglehart, R. 1977. The Silent Revolution. Changing Values and the Political Styles among Western Publics. Princeton, N.J.: Princeton University Press.

Kolanda, M. 1992. Èeskoslovenský prùmysl a jeho národohospodáøské okolí v první etapì reformy (Czechoslovak Industry and its Environment in the First Reform Period). Praha: Prognostický ústav AV ÈR.

Loewenstein, B. 1990. Der Entwurf der Moderne. Vom Geist der bürgerlichen Gesellschaft und Zivilisation. Darmstadt: Deutsche Buchgemeinschaft.

Machonin, P. 1996. "Modernisation and Social Transformation in the Czech Republic." Czech Sociological Review 4: 171-186.

Machonin, P., M. Tuèek 1994. “A Historical Comparison of Social Structures in the Czech Republic in 1984 and 1993." Working Papers 94/4, Prague: Institute of Sociology.

Mlèoch, L. 1992. "The Czechoslovak Economy between the Past and the Future." Prague Economic Papers, no. 3: 209-220.

Müller, K. 1993. Scenario for the Transformation of Science, Technology and Education in the Czech Republic. Prague: Institute of Sociology, Academy of Sciences of the ÈR. 
Novák, M. 1995. "Systémy politických stran a základní modely opozice" (Systems of the political parties and basic models of opposition). Sociologický èasopis 31: 305-320.

Parsons, T. 1949. The Structure of Social Action. Glencoe, IL: The Free Press.

Parsons, T. 1960. Structure and Process in Industrial Societies. Glencoe, IL: The Free Press.

Sennett, R. 1994. Civitas - Die Grossstadt und die Kultur des Unterschiedes. Frankfurt am Main: Fischer Verlag.

Veèerník, J. 1996. “Zmìny na trhu práce a v materiálních podmínkách života v Ėeské republice v období 1989-1995" (Changes in Labour Market and the Welfare in Czech Republic in the period 1989-1995). Praha: Národohospodáøský ústav Josefa Hlávky.

Vláèil, J. 1995. "Profesní a sociálnì politicke orientace èeských manažerù" (Professional and Socio-political Orientations of the Czech Managers). Sociologický èasopis 31: 435-447.

Wallerstein, I. 1991. The Lessons of the 1980s, in Geopolitics and Geoculture. Cambridge: Cambridge University Press.

Weber, M. 1922. Grundriß der Socialökonomik III. Abteilung Wirtschaft und Gesellschaft, Tübingen: J. C. B. Mohr (Paul Siebeck).

Yankelovich, D. 1981. New Rules, Searching for Self-fulfilment in a World Turned Upside Down. New York: Random House.

Zapf, W. 1994. Modernisierung. Wohlfahrtsentwicklung und Transformation. Berlin: Sigma.

Zapf, W., M. Dierkes (ed.) 1994. Institutionenvergleich und Institutionendynamik. WZB Jahrbuch. Berlin: Sigma. 